\title{
$\mathrm{CFRP}$ 시트 및 강섬유로 보강된 RC 보의 충격저항 성능 평가
}

\author{
조성훈 $^{1)} \cdot$ 민경환 $^{1)} \cdot$ 김윤지 $^{1)} \cdot$ 윤영수 $^{1) *}$ \\ 1)고려대학교 건축사회환경공학부
}

\section{Impact Resistance Evaluation of RC Beams Strengthened with Carbon FRP Sheet and Steel Fiber}

\author{
Seong-Hun Cho, ${ }^{1)}$ Kyung-Hwan Min, ${ }^{1)}$ Yun-Ji Kim, ${ }^{1)}$ and Young-Soo Yoon ${ }^{1) *}$ \\ ${ }^{1)}$ School of Civil, Environmental and Architectural Engineering, Korea University, Seoul 136-701, Korea
}

\begin{abstract}
The analysis and experimental program of reinforced concrete (RC) structures for resistance against such extreme loads as earthquake, blast, and impact have been carried by many researchers and designers. Under the extreme loads, a large amount of energy is suddenly exerted to the structure, hence if the structure fails to absorb the impact energy, catastrophic collapse may occur. To prevent catastrophic collapse of structures, reinforced concrete must have adeguate toughness or it needs to be strengthened. The FRP strengthening method and SFRC are studied widely in resistance of impact load because of their high energy absorption capacity. In this study, drop weight impact tests were implemented to evaluate the impact resistance of SFRC and FRP strengthened RC beam while the total steel fiber volume fractions was fixed at $0.75 \%$ carbon FRP flexural strengthened RC beams. Futhermore, to prevent the shear-plug cracks when the impact load strikes the beams, additional FRP shear strengthening method are applied. The experimental, results showed that the FRP strengthened RC SFRC beams has high resistance of shear-plug cracks and crack width and SFRC has high resistance of concrete spalling failure compared to normal RC beams. The FRP flexural and shear strengthening RC beams has weakness in the spalling failure because the impact load concentrated the concrete face which is not strengthened with FRP sheets.
\end{abstract}

Keywords : drop weight impact test, energy absorbtion, SFRC, carbon FRP sheet strengthening, shear-plug crack

\section{1. 서 론}

최근 많은 기술자들과 연구자들에 의해 철근콘크리트 (reinforced concrete) 구조물의 충격저항성능을 향상시키 는 방법에 대한 연구가 진행되고 있다. ${ }^{1-7)}$ 테러에 의한 위협이나 차량 및 선박의 충돌 등 구조물이 기존 설계 하중 보다 높은 극한의 외력에 노출되는 위험도가 높아 지면서 충격과 폭발 저항성능에 대한 요구가 증가하고 있기 때문이다. 충격이나 폭발과 같은 극한 하중에 저항 하기 위해서는 구조물이 에너지를 충분히 흡수할 수 있 는 인성(toughness)을 갖추어야 한다. 철근콘크리트 부재 의 인성을 증가시키기 위한 방법으로는 섬유를 혼입하여 콘크리트의 인성을 증가시키는 강섬유보강 콘크리트 (SFRC), 고인성 시멘트 복합재료(engineered cementitous composite) 등의 고성능 시멘트계 복합체(high performance fiber reinforced cementitous composites)를 사용하는 방법과 부재의 표면을 강판이나 FRP(fiber reinforced polymer)시트 로 보강하여 콘크리트 부재의 인성을 증가시키는 방법을

*Corresponding author E-mail : ysyoon@korea.ac.kr Received May 26, 2010, Revised July 4, 2010,

Accepted July 16, 2010

c) 2010 by Korea Concrete Institute
들 수 있다. ${ }^{8,9)}$ 강섬유보강 콘크리트는 일반 콘크리트와 비교하여 인장, 휨과 같은 응력을 받을 때 강도 및 인성 이 증가한다는 것이 이미 많은 연구들에 의해 검증되었 다. FRP 시트를 이용한 외부 보강방법 또한 1984년 스 위스 연방 연구소(EMPA)에서 $\mathrm{CFRP}$ 보강 방법이 건설 재료로써 활용성이 검증된 이후 고성능 보수 - 보강재로 부재의 휨, 전단 응력에 높은 저항성능을 보이고 있음이 검증되어 현재 다양한 분야에서 사용되고 있다. ${ }^{8)}$

이 연구에서는 강섬유보강 콘크리트와 FRP 시트 보강 의 충격저항성능을 평가하고자 낙하식 충격실험(drop weight impact test)을 수행하였다. 보강된 부재의 충격저 항성능을 평가하기 위하여 $290 \times 160 \times 2,200 \mathrm{~mm}$ 크기의 $\mathrm{RC}$ 보를 제작 $\mathrm{SFRC}, \mathrm{FRP}$ 시트로 보강하여 충격실험을 진행 하였다. 실험을 통해 충격 시 발생하는 shear-plug 균열 양상을 살펴보았으며 각 보강방법에 따른 균열 양상의 진행 및 균열 폭을 측정하였다.

\section{2. 실험 준비}

\section{1 실험 계획}

충격실험에서는 하중이 가해질 때 국부효과에 의해 충 
격을 가하는 물체의 관입현상으로 인한 shear-plugging이 발생한다는 것이 많은 연구에서 보여지고 있다. ${ }^{3-5)}$ 이는 부재의 균열이 하중이 직접 작용하는 부재의 접촉면에서 발생하고 하단으로 발달하는 양상을 보인다. 궁극적으로 shear-plug에 의해 부재의 충격하중이 작용하는 국부에서 하단으로 콘(cone) 모양의 균열이 발생하게 되며 이로 인 하여 부재의 전단파괴가 더 쉽게 발생되기 때문이다. 이 와 같은 현상에 의한 전단파괴의 영향을 고려하기 위하 여 변수를 지정하고 실험을 진행하였다.

부재는 $290 \times 160 \times 2,200 \mathrm{~mm}$ 크기의 보 부재를 제작하 여 부피비 $0.75 \%$ steel fiber와 carbon FRP 시트로 보강 한 후 각 부재의 충격저항성능을 비교하였다. 실험에 사 용된 콘크리트는 $35 \mathrm{MPa}$ 의 일반강도 콘크리트 $(\mathrm{NC})$ 를 Table 1에 나타낸 배합으로 사용하였으며 강섬유보강 콘 크리트(SFRC)의 경우 동일한 콘크리트 배합에 Table 2 와 같은 특성의 길이 $30 \mathrm{~mm}$, 지름 $500 \mu \mathrm{m}$ 의 강섬유를 $0.75 \%$ 의 부피비로 혼입하여 제작하였다. 제작된 콘크리 트 시편의 압축강도 및 인장강도는 Table 3 과 같다. FRP 시트 보강 콘크리트는 carbon FRP 시트를 사용하였으며 에폭시 레진을 이용하여 부착하였다. 보강방법은 보 부 재의 하단을 휨 보강하였으며 사용된 $\mathrm{FRP}$ 와 레진의 특 성은 Table 4에 나타내었다. 각 부재는 28일간 양생 후 실험을 진행하였으며 FRP 시트 보강의 경우 14 일간 양 생된 콘크리트에 시트를 부착한 후 14일을 더 양생하여 완성하였다. Fig. 1은 강섬유 및 $\mathrm{CFRP}$ 의 형상을 보여주 고 있다. RC 보 부재의 철근의 배근 및 상세는 Figs. 2 와 3 에 나타내었다. 전단철근이 없는 $\mathrm{RC}$ 보 $(\mathrm{NC})$ 와 $100 \mathrm{~mm}$ 간격으로 전단 철근을 배근한 $\mathrm{RC}$ 보(NCS)를 두

Table 1 Mixture proportions of concrete

\begin{tabular}{c|c|c|c|c|c|c}
\hline W/C & S/a & \multicolumn{5}{|c}{ Unit weight $\left(\mathrm{kg} / \mathrm{m}^{3}\right)$} \\
\hline $\mathbf{( \% )}$ & $\mathbf{( \% )}$ & Water & Cement & Fine agg. & Coarse agg. & SP \\
\hline \hline 50.0 & 50.4 & 204 & 408 & 876 & 863 & 2.04 \\
\hline
\end{tabular}

Table 2 Properties of steel fiber

\begin{tabular}{c|c|c|c|c}
\hline $\begin{array}{c}\text { Length } \\
(\mathrm{mm})\end{array}$ & $\begin{array}{c}\text { Diameter } \\
(\mu \mathrm{m})\end{array}$ & $\begin{array}{c}\text { Tensile } \\
\text { strength }(\mathrm{MPa})\end{array}$ & $\begin{array}{c}\text { Specific } \\
\text { gravity }\end{array}$ & $\begin{array}{c}\text { Modulus of } \\
\text { elasticity }(\mathrm{GPa})\end{array}$ \\
\hline \hline 30 & 500 & 1,196 & 7.9 & 200 \\
\hline
\end{tabular}

Table 3 Mechanical properties of concrete

\begin{tabular}{c|c|c}
\hline Concrete & $\begin{array}{c}\text { Compressive strength } \\
(\mathrm{MPa})\end{array}$ & $\begin{array}{c}\text { Flexural strength } \\
(\mathrm{MPa})\end{array}$ \\
\hline \hline NC & 39.8 & 6.0 \\
\hline SFRC & 36.7 & 8.7 \\
\hline
\end{tabular}

Table 4 Properties of FRP sheets and epoxy resin

\begin{tabular}{c|c|c|c|c}
\hline Sheet & $\begin{array}{c}\text { Tensile } \\
\text { strength (MPa) }\end{array}$ & $\begin{array}{c}\text { Elastic } \\
\text { modulus (GPa) }\end{array}$ & $\begin{array}{c}\text { Ultimate } \\
\text { strain }(\%)\end{array}$ & $\begin{array}{c}\text { Thickness } \\
(\mathrm{mm})\end{array}$ \\
\hline CFRP & 4,900 & 230 & 2.1 & 0.111 \\
\hline \hline Resin & $\begin{array}{c}\text { Tensile strength } \\
(\mathrm{MPa})\end{array}$ & $\begin{array}{c}\text { Tensile } \\
\text { modulus }(\mathrm{GPa})\end{array}$ & $\begin{array}{c}\text { Ultimate } \\
\text { strain }(\%)\end{array}$ & $\begin{array}{c}\text { Density } \\
\left(\mathrm{g} / \mathrm{cm}^{3}\right)\end{array}$ \\
\hline Epoxy & 90 & 3.0 & 8.0 & 1.2 \\
\hline
\end{tabular}

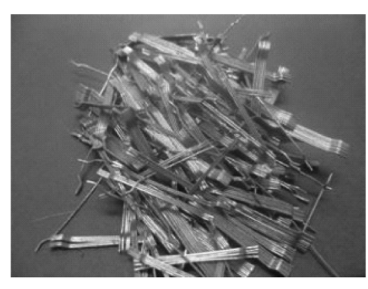

(a) Steel fiber

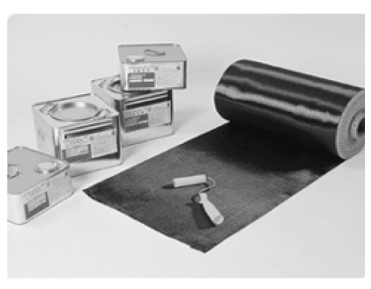

(b) CFRP
Fig. 1 Shapes of steel fibers and FRP sheet

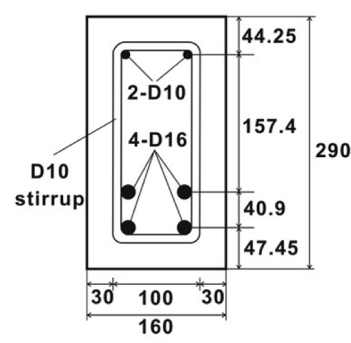

(a) RC beams with shear reinforcement
(Unit : mm)

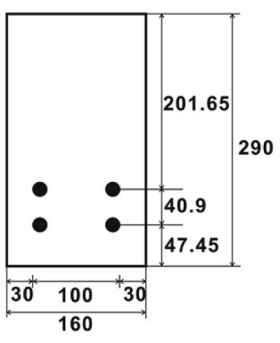

(b) RC beams without shear reinforcement
Fig. 2 Details of reinforcement in RC beams

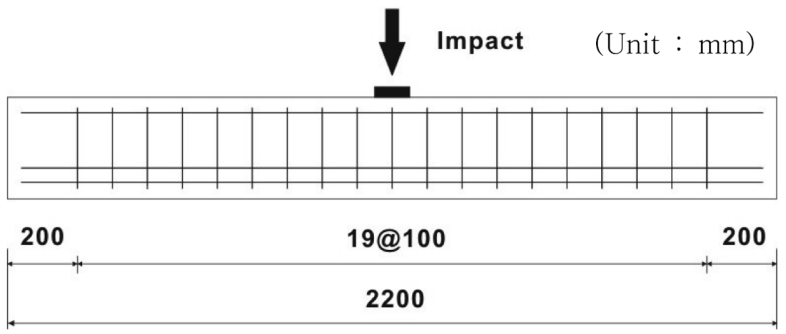

(a) RC beams with shear reinforcement

Impact

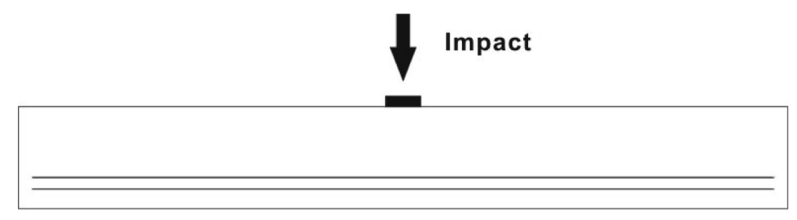

2200

(b) RC Beams without shear reinforcement

Fig. 3 Geometry of the RC beams

어 전단철근에 의한 영향을 살펴보았으며 $\mathrm{SFRC}$ 와 carbon FRP 시트 그리고 2가지 방법을 모두 적용한 부재를 이용 하여 보강방법에 따른 부재의 거동을 비교하였다. 또한 FRP 시트로 균열이 발생하는 부분을 보강함으로써 CFRP 전단보강의 영향을 살펴보기 위하여 Fig. 4와 같이 U형으 로 전단을 추가로 보강한 부재(NCS-CFS, SFS-CFS)를 추 가하여 실험을 진행하였다. 실험변수는 Table 5 에 정리되 어 있으며 각각의 변수에 대한 외형은 Fig. 5 와 같다.

\section{2 충격 실험 방법}

충격하중 실험은 실험기기를 직접 제작하여 진행하였 다. Fig. 6과 같이 부재의 중앙에 낙하 추를 수직으로 떨 


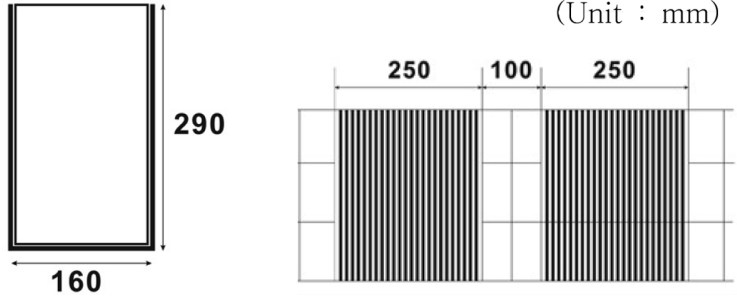

Fig. 4 U-shape CFS strengthening

Table 5 Test variables

\begin{tabular}{c|l|c}
\hline Variable & \multicolumn{1}{|c|}{ Details } & Notation \\
\hline \hline \multirow{4}{*}{ Concrete } & $\begin{array}{l}\text { Normal concrete without shear } \\
\text { reinforcement }\end{array}$ & NC \\
\cline { 2 - 3 } & Normal concrete with shear reinforcement & NCS \\
\cline { 2 - 3 } & $\begin{array}{l}\text { Steel fiber reinforced concrete with shear } \\
\text { reinforcement }\end{array}$ & SFS \\
\hline \multirow{3}{*}{ FRP } & Not retrofitted & NF \\
\cline { 2 - 3 } & Flexural retrofitted with CFRP & CF \\
\cline { 2 - 3 } & Flexural and shear retrofitted with CFRP & CFS \\
\hline
\end{tabular}

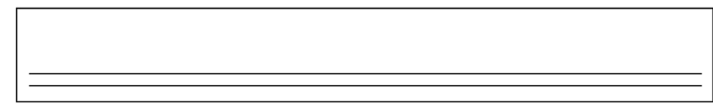

$\mathrm{NC}-\mathrm{NF}$

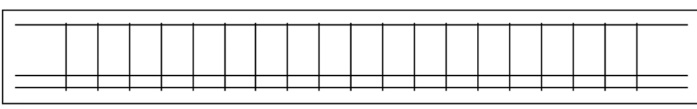

$\mathrm{NCS}-\mathrm{NF}$

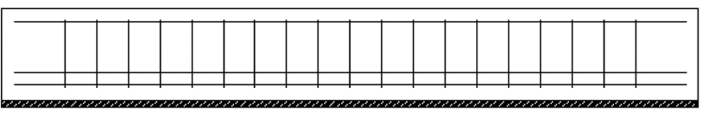

NCS-CF

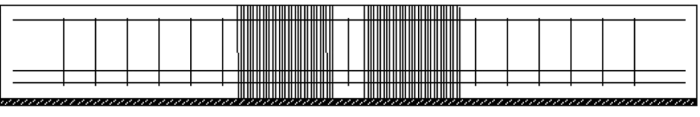

NCS-CFS

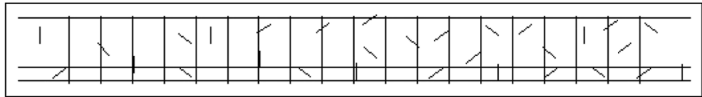

SFS-NF

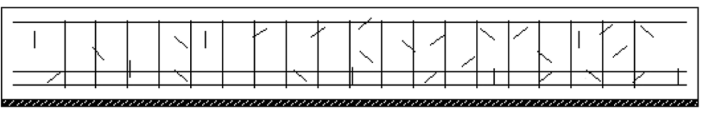

SFS-CF

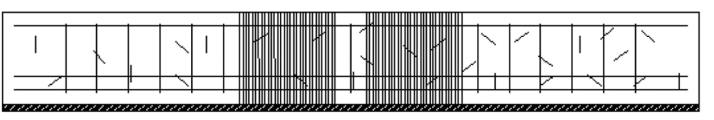

SFS-CFS

Fig. 5 Test specimens

어뜨릴 수 있도록 $\mathrm{H}$ 형 강을 이용하여 추의 가이드를 제 작하였으며 지점부는 충격을 받은 부재가 고정될 수 있 도록 상부를 고정시켰다. 추는 이전에 진행되었던 실험 을 참고하여 여러 번의 충격으로 균열의 발달을 확인할 수 있도록 강판을 이용하여 제작한 후 내부에 콘크리트 를 채워 $150 \mathrm{~kg}$ 의 무게로 제작하였으며 상부에 고리를 만 들어 크레인에 줄을 이용하여 고정할 수 있도록 하였다. ${ }^{3,7)}$
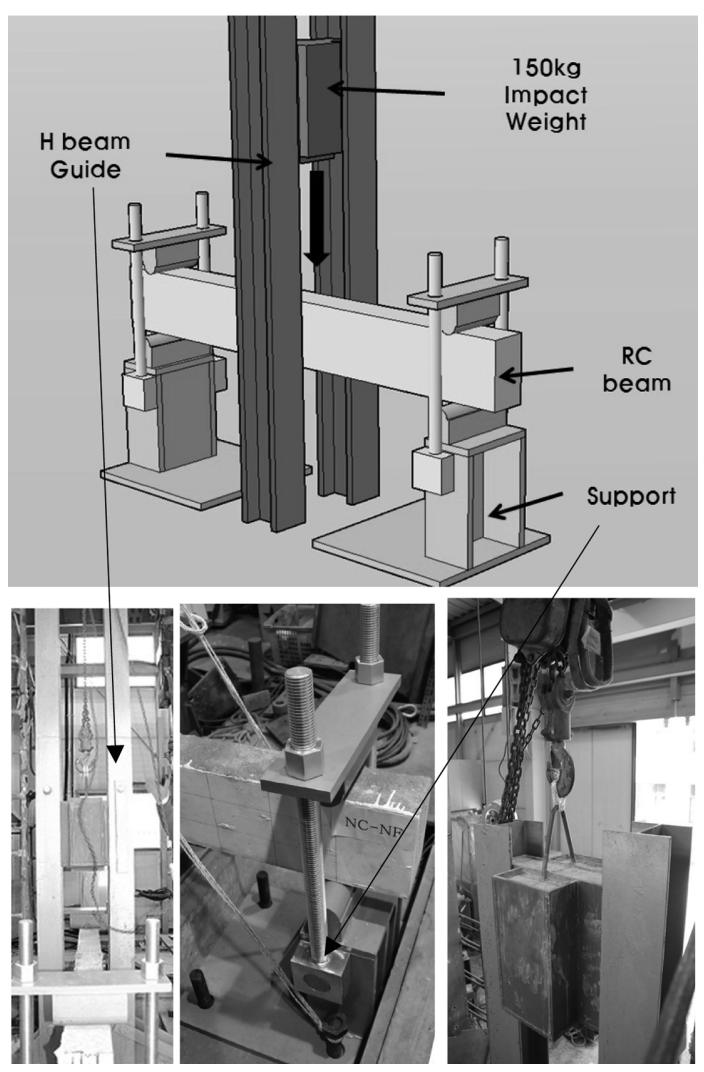

Fig. 6 Test setup

실험은 가이드에 추를 맞춘 후 크레인을 이용하여 끌 어올린 후 줄을 제거하여 추를 낙하시킴으로써 부재에 충격하중이 가해질 수 있도록 수행하였다. 1 회 타격 당 부재에 가해지는 충격에너지는 약 $2.5 \mathrm{~kJ}$ 의 용량이며 추 가 부재에 충격을 가할 때의 낙하 속도는 약 $6 \mathrm{~m} / \mathrm{s}$ 이다. 이는 전단철근이 없는 부재의 실험에서 균열의 진행을 효과적으로 확인할 수 있음을 확인하여 정하였다. 모든 시편은 타격 횟수를 $\mathrm{DS}$ (drop stage)로 구분하여 실험을 진행하여 부재의 충격 성능을 평가 하였으며 shear-plug 균열 및 휨균열 그리고 부 모멘트로 인한 균열이 진행 이 되지 않고 상부의 콘크리트 스폴링 파괴로 더 이상 의 균열이 진행되지 않을 때 까지 실험을 진행하였다. ${ }^{3,4)}$

\section{3. 실험 결과 및 고찰}

각 부재의 실험 결과 모든 부재는 shear-plug 균열 및 부모멘트에 의한 균열 그리고 타격부의 콘크리트 스폴링 파괴가 발생하였다. 콘크리트의 파괴 형상 및 균열 진행 양상은 Fig. 7 에 나타내었으며 각각의 결과는 Table 6과 같다. 충격으로 진행되는 부재의 균열 양상을 보기위해

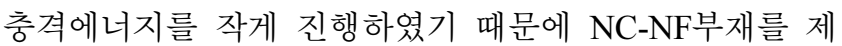
외한 다른 부재에서는 모두 상부의 스폴링 파괴로 인해 더 이상 부재에 충격에너지가 전달되지 않고 국부파괴만 이 진행되었다. NC-NF 부재의 경우 shear-plug와 지점에 서의 전단 균열이 동시에 발생을 하며 $3 \mathrm{DS}$ 에서 지점에 발생한 전단균열에 의해 취성적인 파괴를 보였다. 이는 충격이 부재에 작용할 때 전단철근을 배근하는 것이 취 
성적인 전단 파괴에 효과적으로 저항할 수 있음을 나타낸다.

\subsection{Shear-plug 균열의 비교}

Shear-plug 균열은 부재의 1DS 단계에서 추의 끝부분 에서 발생한 상부균열이 부재의 하단으로 약 2 3DS 단 계까지 진행되어 형성된 콘(cone) 형상의 균열로 측정하 여 Table 6에 길이와 Fig. 7에 굵은 선으로 나타내었다. 전단철근이 없는 NC-NF 부재를 비롯하여 전단철근이 배 근되어 있는 다른 모든 부재에서 shear-plug 균열이 발생 하였으며 DS가 진행 될수록 shear-plug에서의 균열폭이 다른 균열들에 비하여 크게 증가하였다. 실험 결과 발생 한 shear-plug의 균열각은 Table 6에 나타나 있다. 균열각 은 실험중 상부에서 발생한 shear-plug 균열이 하부까지 진행되었을 때 직선으로 가정하여 양쪽의 평균으로 나타 내었다. 실험 결과 CFRP 전단보강이 되어있는 부재(SFSCFS, NCS-CFS)가 shear-plug 균열을 가장 크게 제어하고 있다. 실험진행이 완료된 이후 FRP 시트를 제거하여 살 펴본 결과 $\mathrm{FRP}$ 로 보강된 부위에서는 shear-plug 균열이 발생하지 않는 것을 알 수 있었다. CFRP 전단보강을 한 부재에서는 보강되지 않은 전단 FRP 시트 바깥에서 균 열이 진행되었으며 이는 CFRP 전단보강을 함으로써 보 강된 부분에서 충격하중을 분산시켜 보강되지 않은 부위 에 하중이 집중되기 때문인 것으로 예상된다. 특히나 NCS-CFS부재의 경우 바깥쪽 FRP 계면에서 다수의 균
열을 보이고 있다. SFS부재의 경우 강섬유가 균열을 제 어함으로써 계면에서의 균열도 효과적으로 제어를 하고 있으나 NCS부재의 경우 FRP 계면 상부에서 발생한 균 열이 전단철근의 영향으로 인하여 수직하단으로 발달한 것으로 생각된다.

강섬유보강 콘크리트를 사용한 $\mathrm{SFS}$ 부재와 일반콘크리 트를 사용한 NCS의 경우 강섬유보강 콘크리트를 사용 한 부재가 shear-plug 균열 제어에 효과적임을 알 수 있다. 실험 결과 강섬유보강 콘크리트가 일반콘크리트에 비하 여 shear-plug 균열각이 약 $7 \%$ 작게 나타나고 있으며 이 는 충격으로 발생하는 콘 형상의 부위에 더 많은 전단 철근이 전단파괴에 저항을 할 수 있게 영향을 미치고 있 음을 알 수 있다.

CFRP 시트를 이용하여 휨보강을 한 부재의 경우 shearplug 균열각이 작아지는 경향을 보이고는 있으나 큰 감 소를 보이지는 않고 있다. Shear-plug 균열의 경우 상부 에서부터 균열이 발생하게 되어 단순한 휨 보강만으로는 저항성능에 영향을 미치지 못하기 때문이다. 또한 DS가 진행되면서 Fig. 8과 같이 하부에서 발생한 휨 균열로부 터 콘크리트와 시트의 부분적인 박리 파괴가 일어나게 되 며 중앙에서부터 지점부로 FRP 박리가 진행이 되었다. 이 는 충격하중 시 CFRP 보강된 부재에 발생하는 여러 파괴 모드 중 콘크리트와 시트의 박리파괴가 가장 크게 영향을 미치고 있음을 나타낸다. CFRP 시트로 휨과 전단보강한 부재의 경우 $\mathrm{CFRP}$ 전단보강이 휨보강 된 $\mathrm{CFRP}$ 를 감싸

1DS

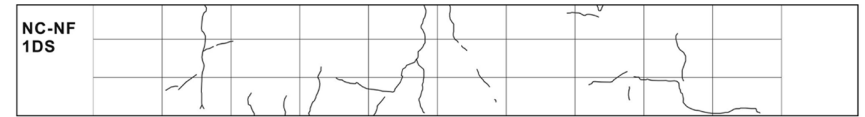

2DS

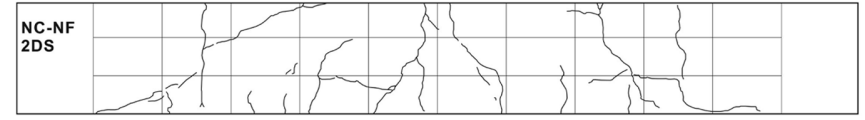

3DS

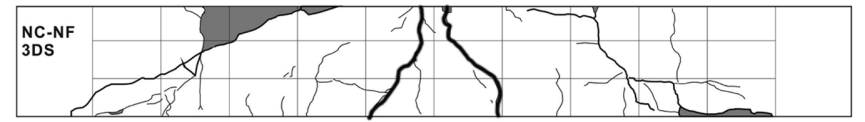

(a) Crack development (NC-NF)

1DS

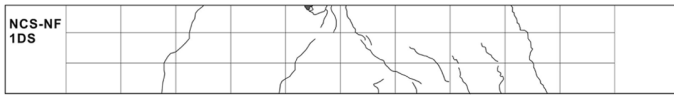

2DS

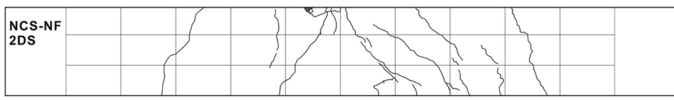

3DS

\begin{tabular}{ll}
\hline NCS-NF \\
3DS
\end{tabular}

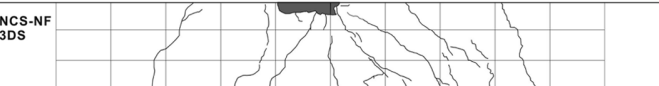

$4 \mathrm{DS}$

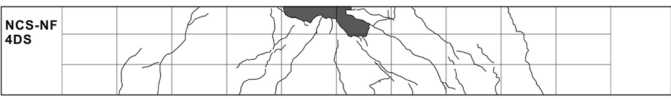

5DS

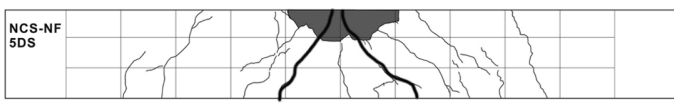

(b) Crack development (NCS-NF)
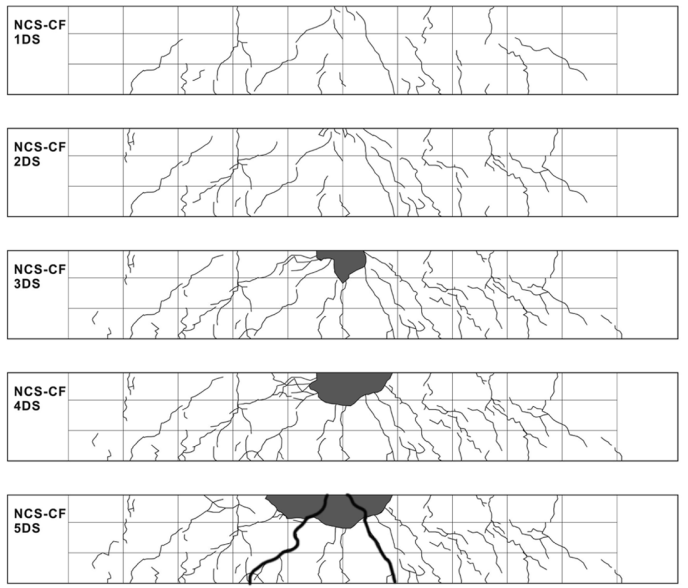

(c) Crack development (NCS-CF)

Fig. 7 Crack development of specimens 
$1 \mathrm{DS}$

2DS

$3 \mathrm{DS}$

$4 \mathrm{DS}$

$5 \mathrm{DS}$

6DS

$7 \mathrm{DS}$

8DS

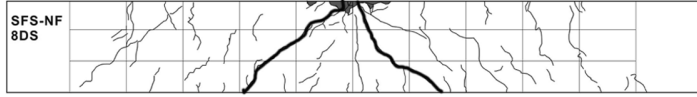

(d) Crack development (SFS-NF)

$1 \mathrm{DS}$

2DS

$3 \mathrm{DS}$

$4 \mathrm{DS}$

5DS
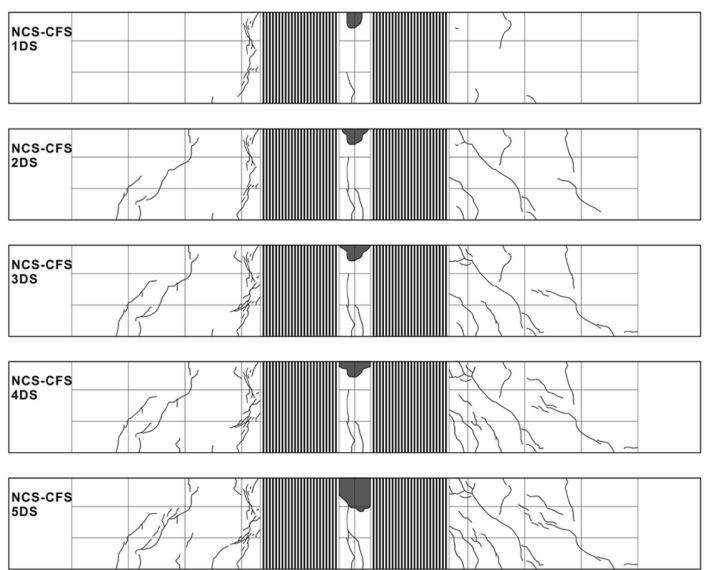

(f) Crack development (NCS-CFS)
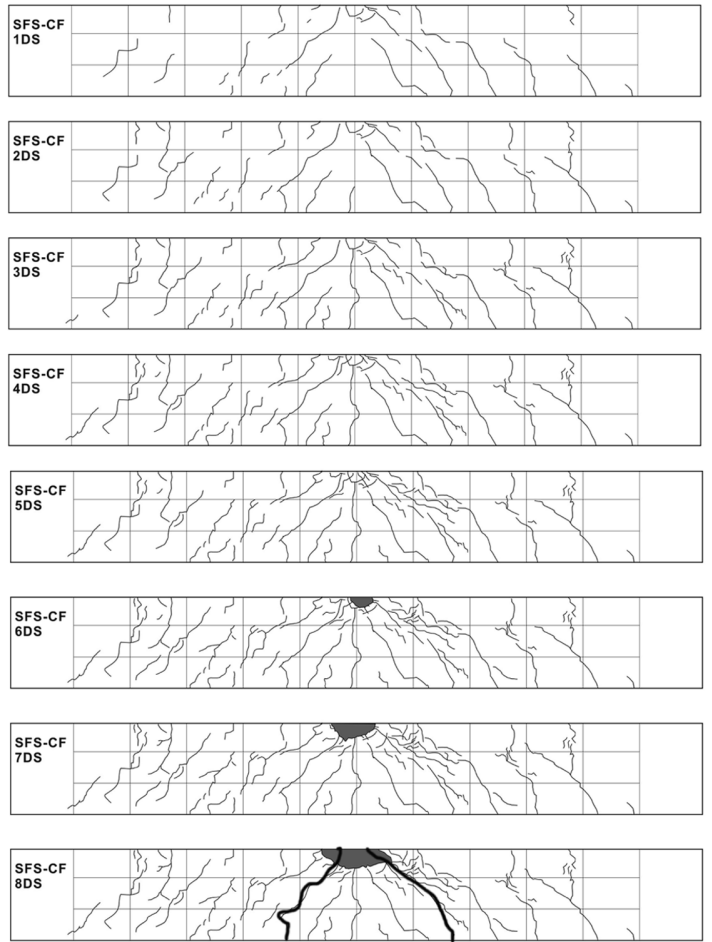

(e) Crack development (SFS-CF)
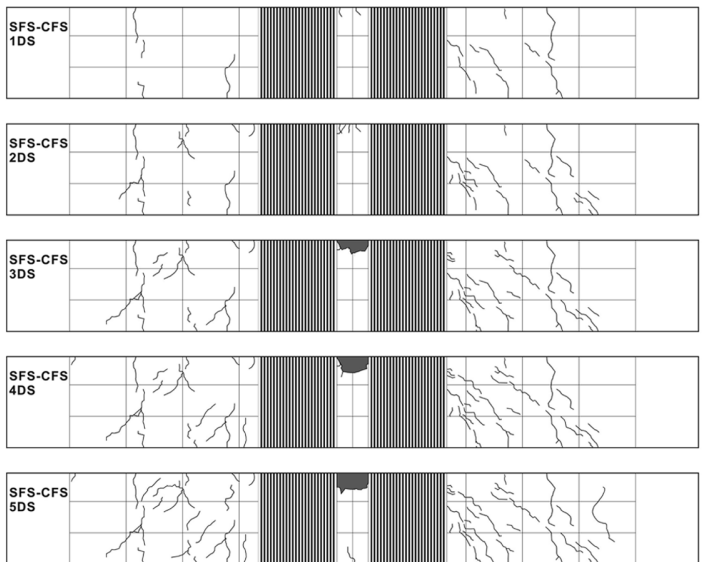

(g) Crack development (SFS-CFS)

Fig. 7 Crack development of specimens (continued)

Table 6 Test results

\begin{tabular}{|c|c|c|c|c|c|c|c|c|}
\hline \multirow{3}{*}{ Variable } & \multirow{3}{*}{$\begin{array}{l}\text { Drop stage } \\
\quad \text { (DS) }\end{array}$} & \multicolumn{2}{|c|}{ Spalling failure } & \multicolumn{3}{|c|}{ Shear-plug crack } & \multirow{3}{*}{$\begin{array}{l}\text { Maximum crack } \\
\text { width }(\mathrm{mm})\end{array}$} & \multirow{3}{*}{$\begin{array}{c}\text { Residual } \\
\text { displacement } \\
(\mathrm{mm})\end{array}$} \\
\hline & & \multicolumn{2}{|c|}{$\stackrel{w}{\stackrel{w}{\rightleftarrows}}$} & & & \\
\hline & & W (mm) & $\mathrm{H}(\mathrm{mm})$ & L1 (mm) & $\mathrm{L} 2(\mathrm{~mm})$ & Degree $\left({ }^{\circ}\right)$ & & \\
\hline NC-NF & $3(2.5 \mathrm{~kJ})$ & - & - & 94.2 & 341.2 & 63 & 8 & 12 \\
\hline NSC-NF & $5(2.5 \mathrm{~kJ})$ & 415.1 & 135.2 & 91.6 & 524.8 & 59 & 0.35 & 5 \\
\hline SFS-NF & $8(2.5 \mathrm{~kJ})$ & 225.5 & 45.6 & 99.2 & 654.9 & 40 & 0.28 & 2.1 \\
\hline NSC-CF & $5(2.5 \mathrm{~kJ})$ & 400.6 & 120.5 & 98.6 & 589.1 & 55 & 0.3 & 4 \\
\hline SFS-CF & $8(2.5 \mathrm{~kJ})$ & 210.1 & 90.2 & 94.2 & 667.2 & 43 & 0.28 & 1.5 \\
\hline NSC-CFS & $5(2.5 \mathrm{~kJ})$ & 280.1 & 130.6 & - & - & - & 0.15 & 1.4 \\
\hline SFS-CFS & $5(2.5 \mathrm{~kJ})$ & 150.5 & 60.5 & - & - & - & 0.1 & 1.4 \\
\hline
\end{tabular}




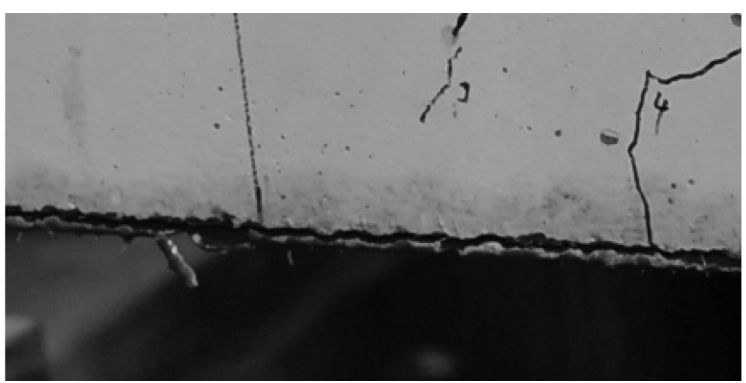

Fig. 8 Debonding failure

게 되어 중앙에서 진행된 균열이 더 이상 지점부로 진행 되지 않고 전단보강이 시작되는 부위에서 더 이상 진행되 지 않았다. 이로부터 충격하중 시 발생하는 FRP 박리파 괴에 전단보강이 저항성능을 발휘하고 있음을 알 수 있다.

\section{2 콘크리트 스폴링(spalling) 파괴의 비교}

실험이 진행되면서 일반콘크리트를 사용한 부재의 경 우 3DS 단계부터 Fig. 9와 같은 콘크리트 스폴링 파괴 가 진행되었으며 강섬유보강 콘크리트 부재의 경우 $6 \mathrm{DS}$ 단계에서 파괴가 진행되었다. 일반 콘크리트 보다 강섬 유 보강 콘크리트의 경우가 최종적인 스폴링 파괴까지 더 많은 타격횟수를 견딜 수 있었다. 강섬유보강 콘크리 트의 경우 NCS-NF부재와 비교하여 스폴링 파괴가 약 $80 \%$ 작은 면적을 보이고 있으며 $\mathrm{SFS}-\mathrm{CF}$ 부재의 경우도 $\mathrm{NCS}-\mathrm{CF}$ 부재와 비교하여 약 $60 \%$ 가 작은 면적으로 측정 되었다. 이는 콘크리트 내에 고르게 분산되어 있는 강섬 유가 타격 시 발생하는 상부의 균열을 효과적으로 제어 하기 때문이며 또한 최종적으로 발생한 스폴링 파괴의 형상에서도 더 작은 면적이 파괴됨으로써 강섬유를 보강 한 콘크리트가 더 좋은 저항성능을 보임을 알 수 있다. CFRP 시트를 이용하여 shear-plug 균열발생 부분을 보강 한 경우에는 오히려 보강을 하지 않은 부재보다 조기에 콘크리트 스폴링 파괴가 일어났다. 이는 추에 의한 타격 이 가해지며 응력이 CFRP 전단보강 사이의 콘크리트에 집중되었기 때문인 것으로 예상된다. 이는 균열제어 및 충격 저항성능 향상을 위해 $\mathrm{CFRP}$ 전단보강을 할 경우 충격하중이 FRP 보강 사이의 콘크리트에 작용 했을 때 오히려 보강을 하지 않은 경우보다 스폴링 파괴에 취약 할 수 있다는 것을 의미하며 충격하중이 작용할 수 있

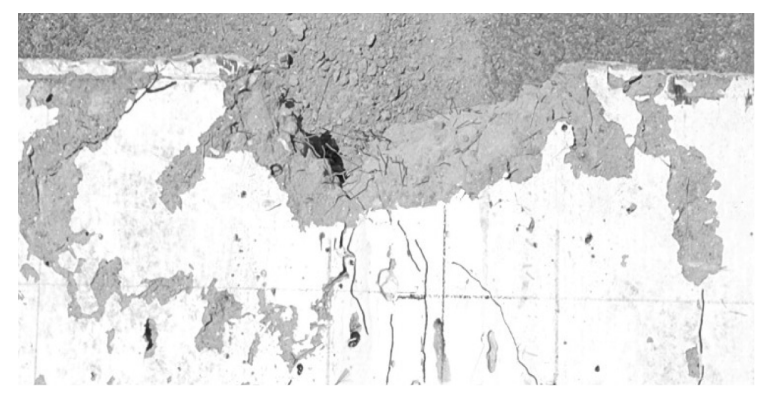

Fig. 9 Spalling failure
는 지점에 대한 충분한 고려를 한 이후 CFRP 전단보강 이 이루어져야 할 것으로 판단되었다.

\section{3 균열 폭의 비교}

균열폭은 모든 부재에서 shear-plug 균열이 가장 크게 측정되었다. 균열폭의 경우 더 많은 균열이 발생한 강섬 유보강 콘크리트가 일반콘크리트에 비하여 작은 균열폭 을 나타내었다. $\mathrm{NF}$ 와 $\mathrm{CF}$ 보강방법 그리고 $\mathrm{NF}$ 와 $\mathrm{CFS}$ 의 보강방법에 따른 균열의 진행양상은 Fig. 10에 나타내었 다. 균열폭 또한 강섬유보강 콘크리트에서 혼입되어있는 강섬유에 의해 콘크리트 내부에서 발생하는 균열에 저항 성능을 발휘하고 있기 때문인 것으로 예상된다. 또한 FRP 시트를 이용하여 휨 보강을 한 경우에도 작지만 균열폭 제어에 저항성능을 발휘하고 있음을 알 수 있다.

\section{4 잔류 처짐}

충격하중의 진행에 따른 부재의 잔류 처짐은 Table 6 과 같이 부재가 전단 파괴된 $\mathrm{NC}-\mathrm{NF}$ 를 제외하고 매우 작 게 측정되었다. $\mathrm{NC}-\mathrm{NF}$ 부재는 최종적으로 전단파괴가 진행되며 실험이 종료된 이 후의 처짐이 $12 \mathrm{~mm}$ 발생하 였으며 NCS부재에서는 약 4 5 mm가 발생하였으며 강 섬유보강이 되어있는 부재에서는 훨씬 더 미미한 처짐이 발생하였다. 잔류 처짐이 작게 측정된 이유는 부재가 저 항할 수 있는 충격하중에 비하여 작은 충격하중이 부재

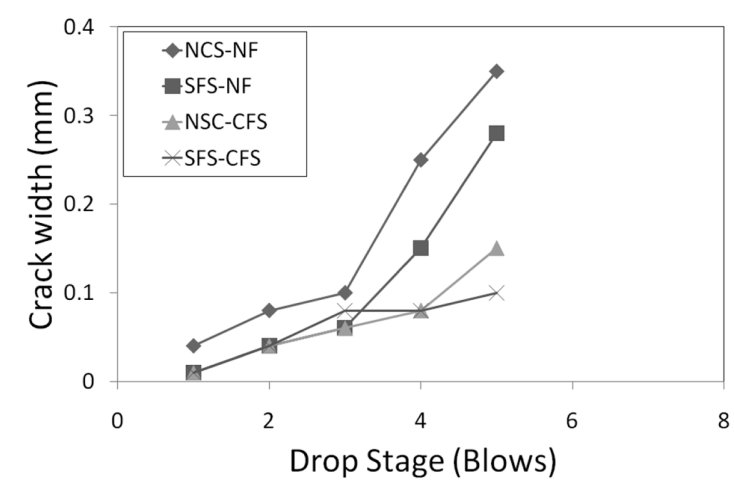

(a) Crack width of NF and CF strengthening

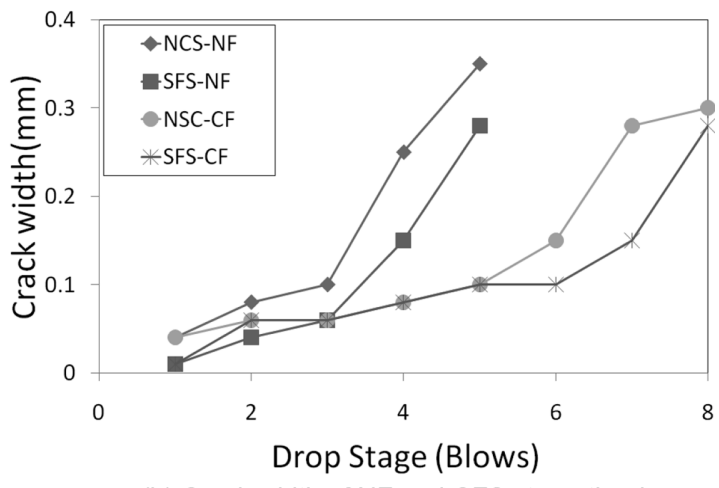

(b) Crack width of NF and CFS strengthening

Fig. 10 Crack width of specimens 
에 작용하면서 최종적으로는 상부의 콘크리트 박리파괴 로 진행되었기 때문인 것으로 보인다.

\section{4. 결 론}

이 연구는 각각의 변수에 따른 부재를 반복적으로 충 격하중을 재하 하여 실험을 함으로써 아래와 같은 결론 을 도출하였다.

1) 전단철근이 없는 일반 콘크리트 $\mathrm{RC}$ 보에 충격하중 이 작용할 경우 shear-plug 균열과 지점에서부터 전 단균열이 발생하며 적은 충격에너지에서 취성적인 전단파괴가 발생하였다.

2) 전단철근을 배근한 RC보의 경우 shear-plug 균열과 부모멘트에 의한 균열 그리고 상부의 콘크리트 스 폴링 파괴가 진행되었다. 또한 반복적인 충격하중 이 작용함에 따라 최종적으로 콘크리트 스폴링 파 괴에 의하여 부재가 파괴되었다.

3) Shear-plug 균열의 경우 강섬유 보강 콘크리트가 균 열각 수치에서 약 $7 \%$ 정도 큰 저항성능을 나타내었 다. FRP 시트를 이용하여 휨 보강을 한 경우 shearplug 균열 자체에는 큰 영향을 보이지는 않았으며 추가적으로 균열이 발생하는 부위에 CFRP 전단보 강을 할 경우 shear-plug 균열이 발생하지 않았다.

4) 스폴링 파괴의 경우 강섬유 보강 콘크리트에서 효 과적으로 제어할 수 있었다. SFS-NF부재의 경우 $\mathrm{NCS}-\mathrm{NF}$ 부재와 비교하여 약 $80 \%$ 작은 파괴 면적을 보이고 있다. CFRP 전단보강의 경우 보강되지 않 은 부위에 응력이 집중되면서 보강하지 않은 $\mathrm{RC}$ 보 에 비하여 더 취약한 결과를 나타내었다.

5 ) 충격에 의해 발생되는 균열폭에 대하여 강섬유를 사용한 부재가 더 작은 균열폭을 나타내고 있으며 또한 FRP 시트로 휨보강을 한 부재가 미미하지만 작은 균열 폭을 나타내고 있다. 따라서 강섬유 보 강 그리고 FRP 시트를 이용한 휨 보강으로써 저항 성능을 높일 수 있음을 알 수 있다.

\section{감사의 글}

이 논문은 2007년도 정부(교육과학기술부)의 재원으로 한국연구재단의 지원을 받아 수행된 연구(No. 20070056796)이다.

\section{참고문헌}

1. 김영우, 민경환, 양준모, 윤영수, “하이브리드 PVA 섬유 를 이용한 HPFRCC의 휨 및 충격 성능 평가,” 콘크리트 학회 논문집, 21권, 6호, 2009, pp. 753 756.

2. 오병환, “철근콘크리트 벽체의 충격거동 및 충격해석연 구," 콘크리트학회 논문집, 4권, 2호, 1992, pp. 705 712.

3. Saatci. S. and Vecchio, F. J., "Effects of Shear Mechanism on Impact Behavior of Reinforced concrete Beams," $A C I$ Structural Journal, Vol. 106 No. 1, 2009, pp. 78 86.

4. Yankelevsky, D. Z., "Local Response of Concrete Slabs to Low Velocity Missile Impact," International Journal of Impact Engineering, Vol. 19, No. 4, 1997, pp. 331 343.

5. Nataraja, M. C., Dhang, N., and Gupta, A. P., "Statistical Variations in Impact Resistance of Steel Fiber-Reinforced Concrete Subjected to Drop Weight Test," Cement and Concrete Research, Vol. 29, No. 7, 1999, pp. 989 995.

6. Li. Q. M., Reid. S. R., Wen. H. M., and Telford. A. R., "Local Impact Effects of Hard Missiles on Concrete Targets," International Journal of Impact Engineering, Vol. 32, Nos. 1 4, 2005, pp. 224 284.

7. Kishi, N. and Mikami, H., "Impact Behavior of Shear-Failure-Type RC Beams without Shear Rebar," International Journal of Impact Engineering, Vol. 27, No. 9, 2002, pp. 955 968.

8. Ishai, O. and Shragai, A., "Effect of Impacts Loading on Damage and Residual Compressive Strength of CFRP Laminated Beams," Composite Structures, Vol. 14, No. 4, 1990, pp. 319 337.

9. Mindess, S., Chen, L., and Morgan, D. R., "Determination of the First-Crack Strength and Flexural Toughness of Steel Fiber-Reinforced Concrete," Advanced Cement Based Materials, Vol. 1, 1994, pp. 201 208.

요 약 최근 콘크리트 구조물에 충격하중, 폭발하중 등 극한의 외력이 작용하는 경우가 빈번하게 발생하고 있다. 이 연구에서는 강섬유보강 RC보와 carbon FRP 시트를 이용하여 보강한 RC보를 이용하여 충격실험을 진행하였다. 강섬유 보강 RC보의 경우 $0.75 \%$ 부피비로 강섬유를 혼입하였으며 carbon FRP 시트의 경우 에폭시 레진을 이용하여 보강을 한 후 보 부재를 완성하였다. FRP 시트 보강은 부재의 하단을 휨 보강하였으며 충격하중이 부재에 작용할 때 발생하는 shear-plug 균열을 제어하기 위하여 충격하중이 가해지는 국부에 CFRP 전단보강을 실시하였다. 실험진행은 drop-weight test 방식으로 직접 기기를 만들어 실행하였다. 각각의 부재에 단계별로 충격하중을 가하여 실험을 진행하였으며 균열과 균열폭을 측정하였다. 실험결과 강섬유보강 RC보가 일반 RC보에 비하여 균열폭 및 shear-plug 균열제어 그리고 스폴링 파괴에 더 높은 성능을 나타내었다. FRP로 부재의 하단을 휨 보강한 부재의 경우 균열의 제어에 어느정도 효과를 나타 내고 있으나 충격하중이 가해질 시 콘크리트와 FRP 시트의 부착면에서 박리파괴가 빠르게 진행되었다. FRP 시트로 부 재의 하단과 측면을 CFRP로 휨, 전단보강한 부재의 경우 shear-plug 균열제어에 가장 높은 저항성능을 보이고 있음을 확인할 수 있었다. 하지만 충격하중이 보강이 이루어지지 않은 부분에 작용할 경우 오히려 보강이 되지 않은 RC보에 비하여 콘크리트 스폴링 파괴에 더 취약함을 알 수 있었다.

핵심용어 : 충격실험, 에너지 흡수, 강섬유보강 콘크리트, Carbon FRP sheet, Shear-plug 균열 